\section{Praktisk veiviser for mage/tarmsykdommer hos barn}

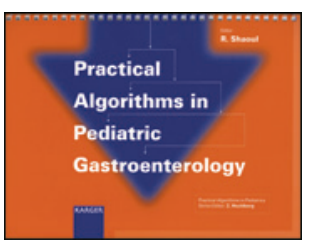

Ron Shaoul, red.

Practical algorithms in pediatric

gastroenterology

110 s, tab, ill. Basel: Karger, 2014. Pris CHF 49

ISBN 978-3-318-02509-5

Dette er den fjerde boken i en serie av håndbøker med praktiske algoritmer for pediatri. I alt er 51 tilstander eller symptombilder omtalt, og inndelt i hovedavsnitt for ulike gastroluminale sykdommer, kirurgiske tilstander, leversykdommer og sykdommer i pancreas. Sentrale fagpersoner fra Europa og USA er ansvarlige for enkeltkapitler, noe som skulle borge for kvaliteten.

Algoritmer defineres gjerne som trinnvise prosesser bygd opp etter en logisk modell for matematisk problemløsning (etter den arabiske matematikeren Algawrismi, mannen bak algebra). Klinisk diagnostikk baseres ofte på bevisst eller ubevisst bruk av algoritmer. Som hjelpemiddel til raskere å forstå en problemstilling kan nedskrevne algoritmer være til nytte både for erfarne og mindre erfarne klinikere.

Boken er bygd opp med et beslutningstre per oppslag, der motstående side har forklarende tekst og referanser. Figurene er oversiktlige med lite tekst og få punkter, men gir lite mening uten bruk av den forklarende teksten. Samtidig er disse støttetekstene ofte gode punktvise oppsummeringer, gjerne supplert med tabeller.

Den praktiske tilnærmingen er bokens styrke; ett eksempel er kapitlet om fremmedlegemer, der lærebøker gjerne blir for ordrike og lite praktiske. Mange klinikere vil nok ha nytte av å støtte seg på kapitlet som tilrår å avvente endoskopisk fjerning av gjenstander som har nådd ventrikkelen, som ikke gir symptomer og ikke er etsende eller skarpe. Andre temaer er imidlertid såpass omfattende at algoritmene gir lite praktisk hjelp, for eksempel kapitlet om residiverende magesmerter. Uten god bakgrunnskunnskap om funksjonelle tarmlidelser og andre vanlige årsaker til magesmerter antar jeg at dette kapitlet gir begrenset nytte. En god oversiktsartikkel vil være mer relevant.

I Sverige blir praktiske manualer som denne gjerne omtalt som en «lathund» - en snarvei eller løsning for latsabber - når man ikke kan lese mer omfattende litteratur. Tekstbøker eller oversiktsartikler kan ikke erstattes med enkle algoritmer eller kliniske «kokebøker». I denne boken gir referanselistene nyttige tips for bedre innsikt i temaene. Som lettfattelig støtte i en travel klinikk tror jeg denne utgivelsen vil være nyttig for mange av oss.

\section{Ketil Størdal}

Overlege, Barneavdelingen

Sykehuset Østfold

Fredrikstad

\section{Lærebok i klinisk ernæring}

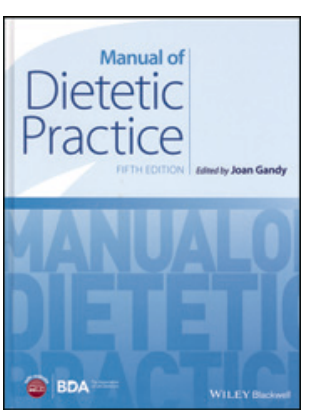

Joan Gandy, red.

Manual of dietetic practice

5. utg. 998 s, tab, ill. Chichester

Wiley-Blackwell, 2014. Pris GBP 85

ISBN 978-0-470-65622-8

Manual of dietetic practice er én av flere bøker som brukes i utdanningen «master i klinisk ernæring» ved universitetene i Oslo og Bergen. Kliniske ernæringsfysiologer er autorisert helsepersonell med en økende grad av spesialisering. Denne boken tar, så langt som mulig, høyde for noen grad av spesialisering, men stort sett er den egnet $\mathrm{i}$ undervisning av studenter.

Boken har to deler. Del 1 dekker til en viss grad emner som vil være en repetisjon for studenter på masternivå, som vurdering av ernæringsstatus, vegetarisk kosthold, sportsernæring, genetikk og genomikk, «drug-nutrient interaction», funksjonell mat, folkehelseernæring og kosthold hos personer med ulik etnisk bakgrunn. Del 1 inneholder også, i motsetning til tidligere utgaver av boken, ca. 60 sider om pediatrisk ernæring, men den er likevel ikke førstevalget $\mathrm{i}$ studentenes pediatriundervisning.

I del 2 dekkes sykdomslære, prognose, medisinsk behandling og ernæringsbehandling av primært «voksensykdommer», som underernæring generelt, enteral og parenteral ernæring, luftveissykdommer, mage- og tarmsykdommer, nyresykdommer, nevrologiske sykdommer, muskel- og skjelettsykdommer, hjerte- og karsykdommer, kreftsykdommer, palliativ behandling, mental helse, immunologiske sykdommer, fedme, endokrinologiske sykdommer, traumebehandling, perioperativ ernæring og så videre.

Som andre lærebøker er også denne til en viss grad ferskvare. Boken inneholder navn, spesialitet og arbeidssted på de om lag 160 forfatterne og er naturligvis preget av disse. Det finnes en del referanser i tilknytning til hvert kapittel, og man skal være kritisk til valg av referanser.

Boken skal brukes i undervisning av studenter i klinisk ernæring. Kliniske ernæringsfysiologer, som kjenner de forskjellige temaene godt, skal kommentere og supplere innholdet med oppdatert kunnskap.

Det er den som bruker boken i undervisning, som må se til at innholdet speiler oppdatert kunnskapsbasert viten. Ett eksempel er feilsitering av referanse på side $667 \mathrm{i}$ boken. I boken står det: «It is considered that over $90 \%$ of atopic eczema in infants is caused by milk, egg, peanut and soya (Hill et al., 2008).»

I den ene referansen som ligger til grunn for denne påstanden, står følgende i konklusjonen: «Our findings lend support to the important association between high levels of $\operatorname{IgE}$ sensitization to dietary antigens and eczema in early infancy.» Dette er kun ett eksempel på viktigheten av å satse på god studentundervisning!

Mette Helvik Morken

Førsteamanuensis II, Klinisk institutt 1

Universitetet i Bergen 